\title{
SUBSTANCE ABUSE AMONG ELEMENTARY SCHOOL PUPILS: PREVENTION AND EARLY INTERVENTION
}

\author{
Antonia Kocijančić, BA in preschool education, \\ Volunteer in the Kindergarten and Day Care Centre "Radost" in Poreč, \\ Branch Day Care Centre in Kaštelir (Croatia) \\ e-mail: antoniakoc@hotmail.com \\ Mirjana Radetić-Paić, PhD \\ Department of educational sciences, \\ Juraj Dobrila University of Pula (Croatia) \\ e-mail: mradeticpaic@ hotmail.com \\ Maja Ružić Baf, PhD, assistant prof. \\ Department of educational sciences, \\ Juraj Dobrila University of Pula (Croatia) \\ e-mail: maja@infosit.hr
}

\begin{abstract}
S u m m ary
The general aim of this research is to obtain an insight into substance abuse among the pupils of the elementary school Jože Šuran in Višnjan - Branch School in Kaštelir, with the purpose of planning preventive and early interventions aimed at substance abuse, as well as a possible conduction of a further research on a larger sample of examinees. The specific aim is to determine the differences in the use of addictive substances according to age (grades) of pupils, since the risk of experimenting with some addictive substances increases in the adolescence period.

The obtained results show a relatively favourable relation between the pupils of the examined school toward substance abuse and are a valuable contribution to the planning of preventive and early interventions regarding this problem.

Key words: abuse of addictive substances, elementary school pupils, adolescence, prevention, early interventions, Kaštelir

Substance abuse among the young population represents today a multi-layered and extremely complicated problem and an occurrence with many undesirable results for the society. Young people's addictive behaviour is a serious social, educational and social and political problem. Suppressing addictive behaviour of the young is a long lasting process for which a constant and complete social action is needed to remove the factors which contribute to the occurrence and spreading of such behaviour.
\end{abstract}

\section{Introduction}


In the last ten years, the accessibility of drugs has become higher in the Republic of Croatia, leading to an increased consumption of addictive substances among young people. It can be concluded that the Republic of Croatia, up to some years ago, was among the countries where alcohol, cigarettes and drugs were widespread, with an increasing tendency of consumption. According to the Croatian Public Health Institute data (2010) on the epidemiology of addiction in the Republic of Croatia, the average age for the first use of any psychoactive substance is $15.9-16.0$ years of age. The first use of heroin happens in the 20s, and the first intravenous intake happens at the age of $20.6-$ 20.8 , not a full year after that.

Adolescence is a specific developmental period in the life of each single person, characterized by many changes on the physical, social and emotional plan. The beginning, lasting and end of this developmental period are individual, but the first changes can be noticed around the eleventh and twelfth year of age (pre-adolescence). Still, the major changes, the worse difficulties, start to occur after the fourteenth year of age, usually with the transition to high school, which is by itself an important change in the life of a young person.

Adolescents belong neither to the group of children nor adults. In this period the process of separation and development of identity begins. Adolescence brings along many changes in the behavioural and emotional plan, and emotional instability, depression, anxiety, aggression and a burning need for becoming adults, developing one's own individuality and identity can be noticed. All that represents a fertile soil for substance abuse. Namely, a large and branched market of addictive substances is constantly looking for new consumers. Young people with some of the forwardly mentioned characteristics in the process of growing up are its easy target. Although it is usually about experimenting with addictive substances, a part of young people does not succeed in keeping control and continues taking such substances, which leads to addiction and a wider group of hard-to-solve problems (Petak, 2005).

Children's school population is very heterogeneous, but the largest number of them still belongs to the group of low-risk children who go through this "crisis" period without experiencing major problems. One of the perils which adolescents come across is experimenting with psychoactive substances. Researches have established that 50 to 60 percent of high school pupils come into contact with a kind of drugs before the end of their schooling

(http://www.prevencija-ovisnosti-split.org/druga_casopis.asp?id=11).

World's experiences show that despite numerous campaigns about harming effects of addictive substances on mental and physical health, first of all the brain and cognitive functions, the consumption of alcohol, cigarettes and drugs among the young does not decrease (Aarons and partners, 1999; Iverson, 2005).

It is known that just one pill of ecstasy can cause permanent changes to the brain, even death, and that marijuana permanently damages memory and cognitive functions. The effects on these brain functions are higher with adolescents than with adults. However, despite access to information, a large number of young people will reach out for some addictive substances. The young are influenced by various global and subcultural trends and they create their own system of values which is significantly different from the adults' system of values. A larger number of young people are attracted by different trends acceptable to their age, while the influence of peer groups 
and their attitudes is extremely high in these ages. In this sense, the young tend to look for new experiences and new knowledge. Researches have also shown that the consumption of addictive substances is linked to the family environment in which parental support and parents' low familiarity with persons their child frequents are very low (Kocijančić, 2010). It has been established that adolescents who live in families where conflicts are common and where there is inadequate education (Radetić-Paić, 2005), and adolescents who do not have social support or personal strength in facing stressful situations, use addictive substances more intensively. At the same time, a stressful life situation for children is also the transition from elementary to high school, change of school and environment or poor school success.

The causes of substance abuse are various, and it is possible to group them in three larger groups:

- Personality - the features of the addict's personality (drug, alcohol or cigarettes addict) show a low tolerance of frustrations, low self-esteem, depression, passivity, the feeling of inferiority or guilt, narcissism, disorientation, instability, emotional immaturity, inability or difficulty in expressing one's emotions and conditions and unreadiness to decide about one's own existence.

- Addictive substances - the substance by which an addict (drug, alcohol or cigarettes addict) reaches the desired condition of euphoria and happiness where all problems disappear and everything becomes "idyllic."

- Social environment - it plays the role of the young person's educator, but usually it does not fulfil this role. Today's society gives the young person a sense of loneliness, isolation and abandonment. A young person runs away from such a world into a world of addiction where he or she feels, at least to a certain degree, "accepted" and "understood" (Bašić, 1995).

It is important to emphasize the indicators collected within the European School Survey Project on Alcohol and Other Drugs (ESPAD), a cooperation project of independent research teams, mostly from European countries, on 105,000 pupils. The project was carried out four times in Croatia, completed and coordinated by the Croatian Public Health Institute. Data collected in the 2007 ESPAD survey (http://www.hzjz.hr/skolska/Sazetak_ESPAD_2007.pdf) show the following:

- When it comes to smoking cigarettes among pupils, 50 to 80 percent of pupils in almost all countries have tried smoking cigarettes at least once in their life. In Croatia smoking is more widespread than the average in other countries -38 percent of boys and girls have smoked in the last 30 days. These trends are stabilized for boys, but they are on the increase for girls, which makes the difference between sexes disappear.

- In most countries the survey has shown that almost all male or female pupils have abused alcohol at least once in their lives (90 percent or more), but not all children drink often or regularly. To assess drinking, indicators of alcohol consumption in the last 12 months ( 82 percent) and in the last 30 days (61 percent) have been chosen. All the indicators of drinking are higher in Croatia than the average in other surveyed countries. According to the survey, 84 percent of young people in Croatia have drunk alcohol at least once in the last 12 months (compared to 82 percent in other countries), while 64 percent of them have drunk in the last 30 days (compared to 61 percent in other 
countries). Forty-three percent of young Croatians have stated to have been drunk at least once in the last 12 months (compared to 39 percent in other countries). The category of excessive drinking has shown that in the last 30 days 50 percent of young Croatians have drunk excessively which is again higher than the average 43 percent in other countries.

- The largest number of pupils experimenting with psychoactive drugs has tried marijuana and hashish. On average 23 percent of boys and 17 percent of girls have tried some of the illegal drugs before the survey. 21 percent of boys and 16 percent of girls in Croatia have tried marijuana at least once in their lives, which places Croatia below the average of ESPAD countries. It also shows a diminution in consumption compared to the 2003 survey. Other used psychoactive substances are ecstasy, cocaine and amphetamines (about 3 percent each), and rarely heroin, LSD and crack (1 to 2 percent) (http://www.hzjz.hr/skolska/Sazetak_ESPAD_2007.pdf).

Following the obtained indicators the need of investment in preventive and early intervention programmes against substance abuse in pupils' preadolescent and adolescent years has been proved.

\section{Aim, purpose and hypothesis of the research}

The general aim of this research is to obtain an insight into the abuse of intoxicating substances by the pupils of the elementary school Jože Šuran in Višnjan branch school in Kaštelir, with the purpose of planning preventive and early interventions aimed at substance abuse, as well as a possible conduction of a further research on a larger sample of examinees.

The specific aim is to define the differences between the uses of addictive substances according to age (grade) of pupils. The following hypothesis has been set:

$\mathbf{H}_{\mathbf{1}}$ : There are differences in the use of addictive substances according to age (grade) of pupils.

The hypothesis is based on assumptions that the risk of experimenting with some addictive substances becomes higher with adolescence. Namely, very complex and deep changes at the physical, emotional, intellectual, ethical and social level happen in the transition from childhood to the world of adults. Many authors (Freud, 1958; Blos, 1962 in Freud, 2000) have agreed that in working with adolescents the most difficult thing is to set the limit between what is normal and what is pathological. To what extent the difficulties will happen depends on the past development of a person, as well as on the person's environment, which can make the process easier or more difficult. In the context of addiction occurrence, the authors Brousselle, Gibeault and Vincent (1980) think that adolescent crisis happens in the form of two major groups of occurrences. One of these groups leads to psychopathological occurrences which harm one's life, and the most common between them is the occurrence of addiction.

\section{Sample of examinees}

The sample of respondents included 42 pupils of the Jože Šuran Elementary School in Višnjan - Branch School in Kaštelir. There were 28 male pupils and 14 female 
pupils in the sample. The respondents were distributed according to age (grade) and sex as follows:

- 13 pupils of the sixth grade (10 boys and three girls),

- 17 pupils of the seventh grade (nine boys and eight girls),

- 12 pupils of the eighth grade (nine boys and three girls).

\section{Sample of variables} variables:

The questionnaire constructed for the purposes of this research consisted of eight

1. Have you ever consumed alcohol?

2. How often do you consume alcohol?

3. Have you ever smoked cigarettes?

4. How often do you smoke cigarettes?

5. Have you ever tried some kind of drugs (pot, pills,...)?

6. How often do you consume this kind of drugs?

7. Do you consider yourself addicted to a kind of addictive substance to the extent that you could not do without them any more (cigarettes, alcohol,...)?

8. Do you think you are sufficiently and properly informed about this problem?

\section{Methods of data processing}

Along with the computation of absolute and relative frequencies, the $x^{2}$ test was used in data processing.

\section{Methods of conducting the research}

The research was carried out by pupils filling in the questionnaire about the consumption and frequency of consumption of some addictive substances by themselves. The research was voluntary and anonymous, carried out in agreement and cooperation with the employees of the school in question. The data were later used for the purposes of this research.

\section{Results and discussion}

Results shown in Chart 1, which shows pupils' answers about the consumption of alcohol, indicate that eighth graders (75 percent) consumed alcohol more often that sixth graders (53.8 percent) and seventh graders (47.1 percent). In the sixth and seventh grade there were more pupils who consumed alcohol than those who did not.

The value of the $x^{2}$ test for the variable consumption of alcohol leads to the fact that these indicators are not statistically significant. 
Chart 1 Have you ever consumed alcohol?

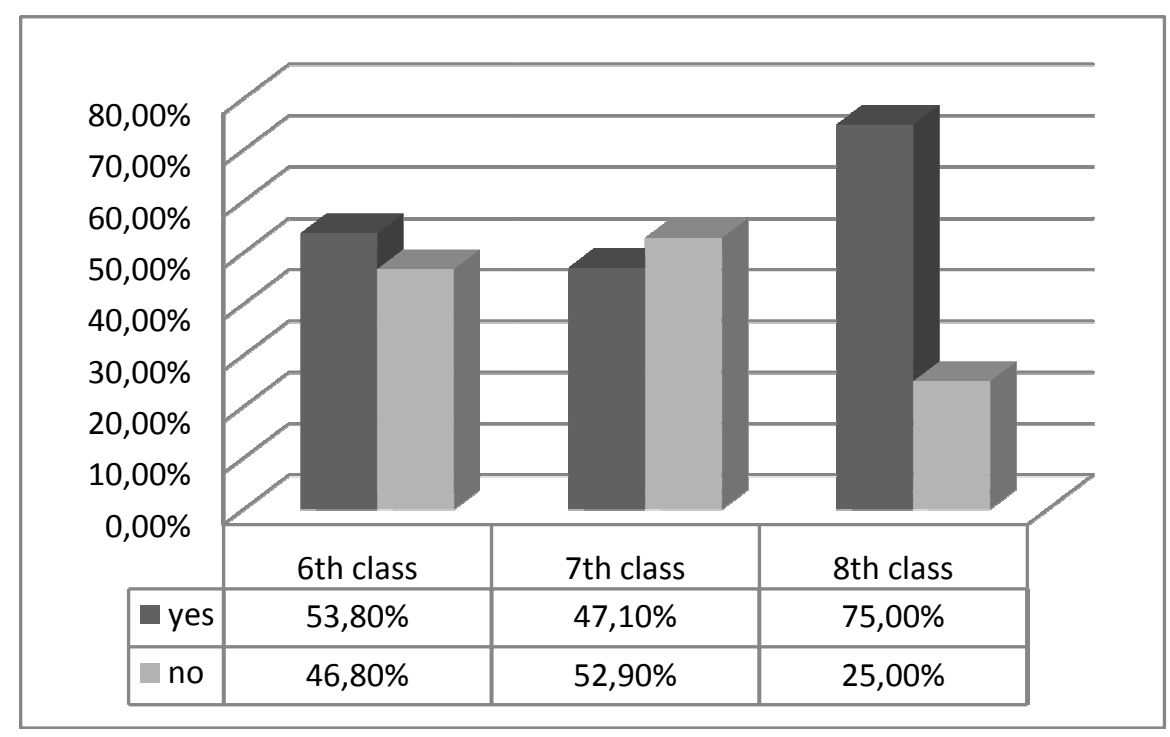

$x^{2}=2,326 ; d f=2 ; p=.313$

Chart 2 shows that about half of the pupils from all surveyed classes do not consume alcohol. It is interesting that eighth graders show more favourable data about the frequency of alcohol consumption compared to the seventh graders in terms of rare consumption, or to the sixth graders in terms of frequent consumption of alcohol.

Chart 2 How often do you consume alcohol?

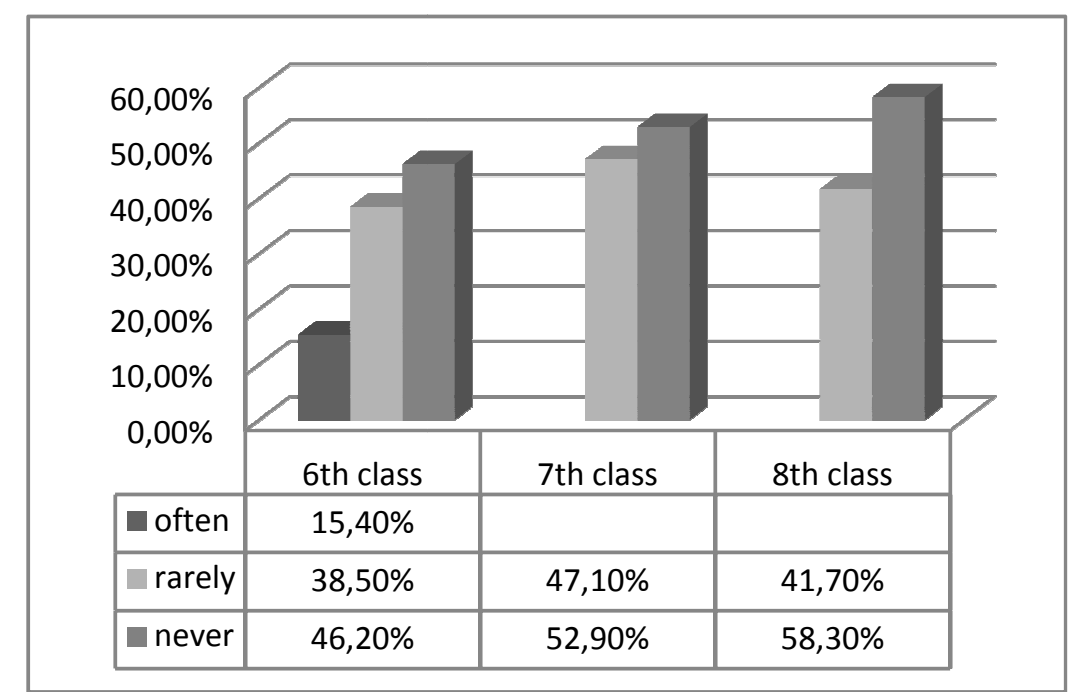

$x^{2}=14,773 ; d f=4 ; p=.031$ 
Chart 3 Have you ever smoked cigarettes?

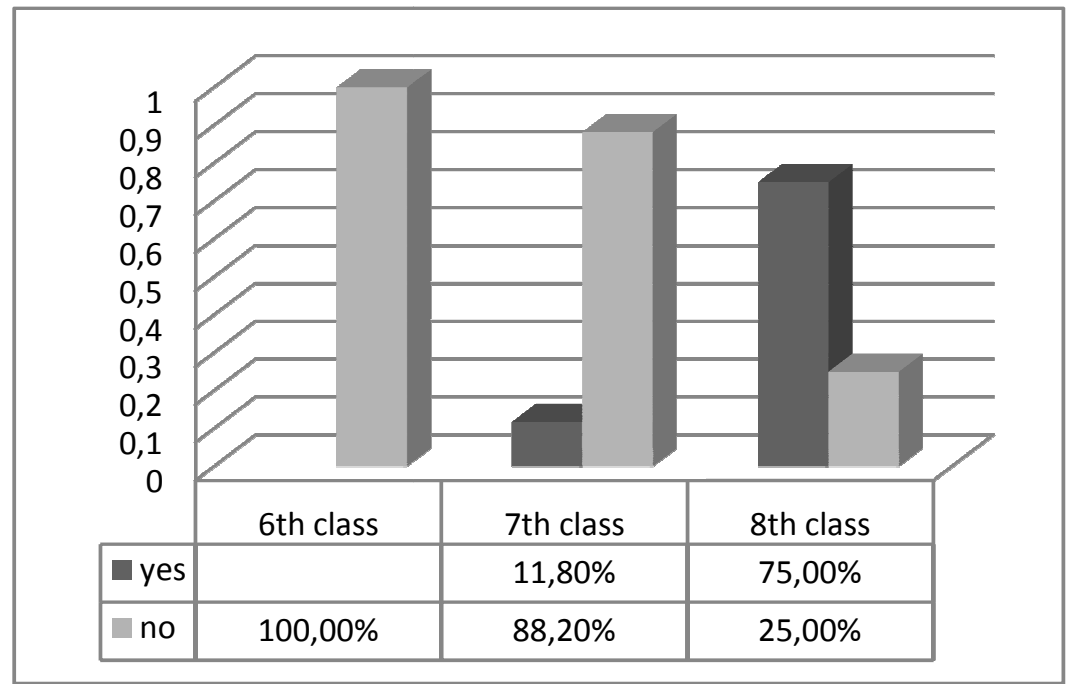

$x^{2}=21,232 ; d f=2 ; p=.000$

When it comes to the frequency of consumption of alcohol among pupils, the $x^{2}$ test is higher than the marginal value at the fourth level of freedom, which means that the indicators can be seen as significant, not accidental.

Indicators about smoking cigarettes (Chart 3) show that eighth graders smoked cigarettes to a more significant extent than the sixth and seventh graders. It is encouraging that sixth graders did not smoke cigarettes at all, while an increase was noticed in the seventh (11.8 percent) and eighth grade ( 75 percent) of elementary school. The increase in smoking cigarettes can be explained by the tendency of young people to show themselves as more adult and older. Young people at these ages can show forms of behaviour which do not necessarily need to represent behaviour disorders, but they can turn into ones.

For the variable smoking, the $x^{2}$ test is higher than the marginal value at the adequate level of freedom, which means that the indicators can be taken as significant, not accidental.

It is encouraging that pupils who smoked (Chart 4), seventh and eighth graders, did this rarely.

The value of the $x^{2}$ test for the variable frequency of smoking cigarettes among pupils is higher than the marginal value at the second level of freedom, which means that the indicators can be taken as significant, not accidental. 
Chart 4 How often do you smoke cigarettes?

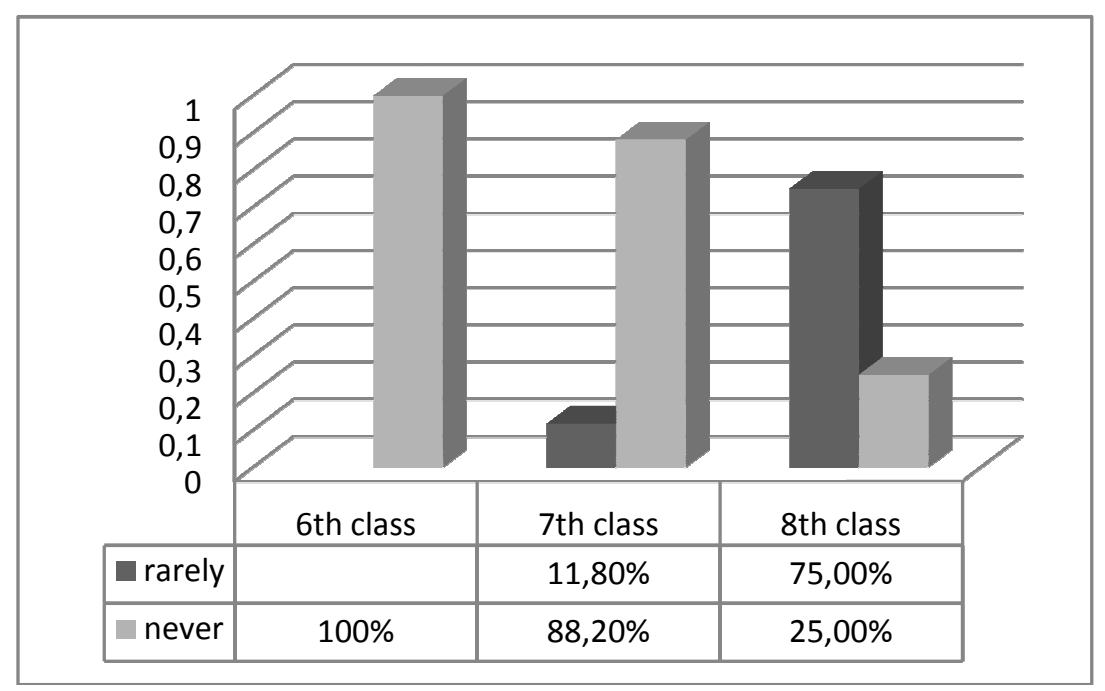

$x^{2}=21,232 ; d f=2 ; p=.000$

Chart 5 Have you ever tried some kind of drugs (pot, pills,...)?

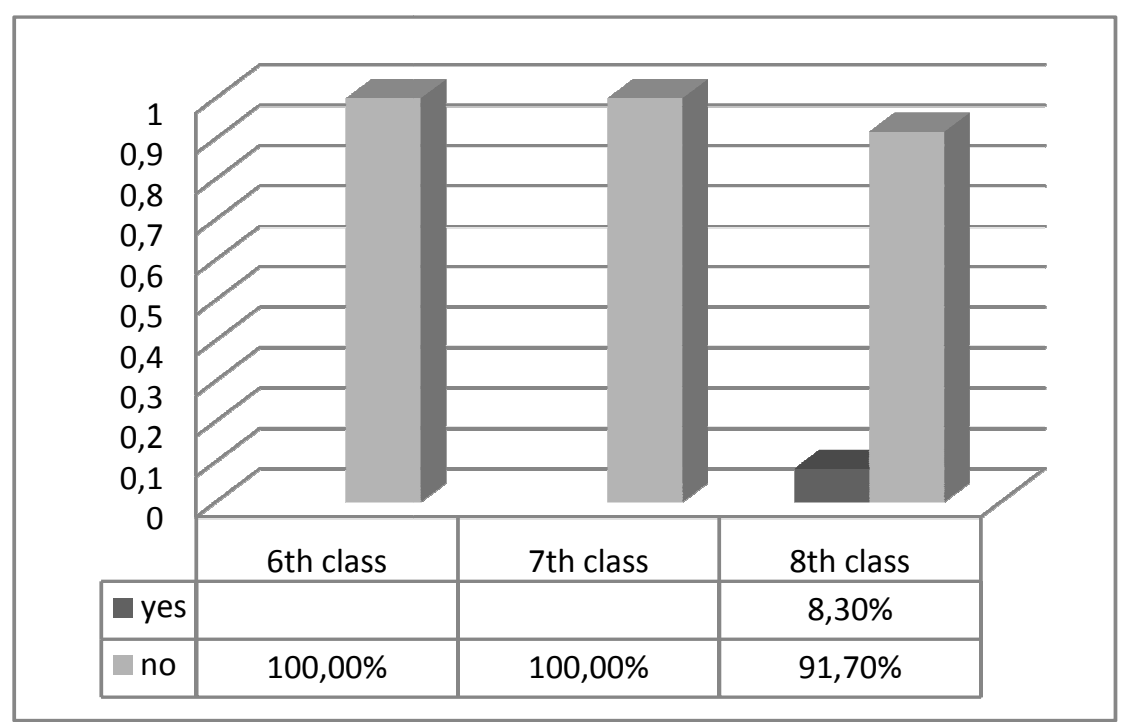

$x^{2}=2,561 ; d f=2 ; p=.278$

Chart 5 shows that the surveyed elementary school pupils mostly did not experiment with various addictive substances. Only 8.3 percent of pupils of the eighth grade tried some kind of drugs. When taking into consideration the relatively small sample of respondents, it comes down to just one pupil. 
The value of the $x^{2}$ test for the variable related to experimenting with some drugs is not statistically significant.

In general, pupils who link positive experiences to school consume addictive substances more rarely than those who evaluate school negatively (Maddox and Prinz, 2003) although this has not been researched here.

The eight grader who tried drugs, did that rarely (Chart 6). However, the result for the $x^{2}$ test for the variable frequency of consumption of some drugs is not statistically significant.

The data in Chart 7 show that pupils did not consider themselves to be addicted to any kind of addictive substance.

The $x^{2}$ test for this variable has not given any value since this variable is constant because nobody considered themselves addicted.

Chart 6 How often do you consume a kind of drugs?

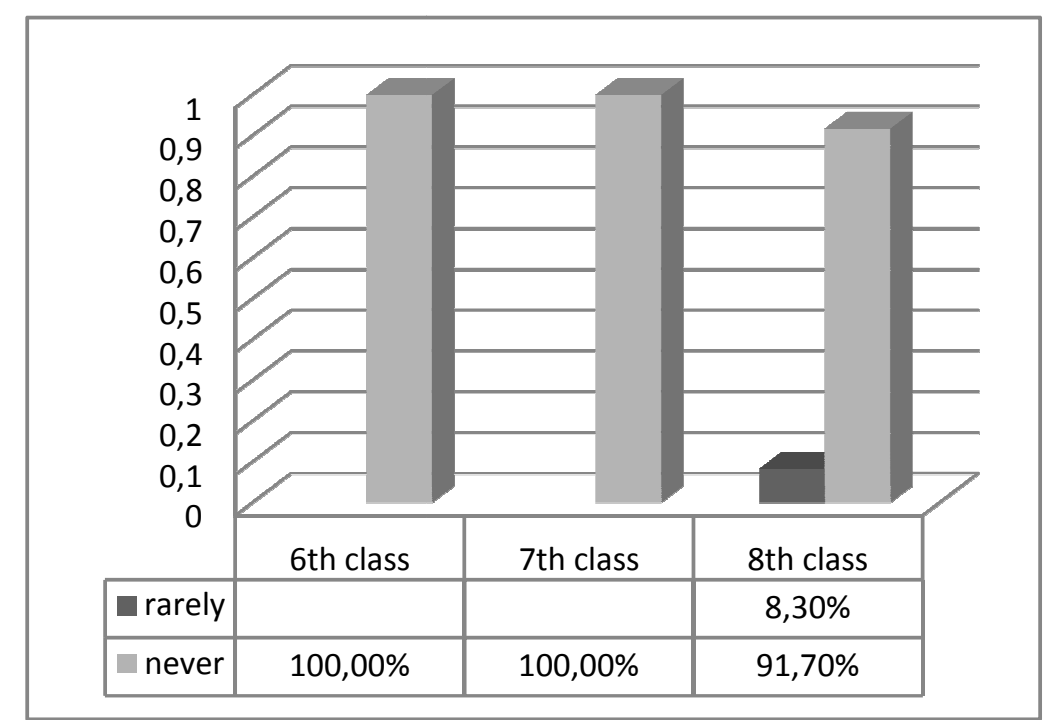

$x^{2}=2,561 ; d f=2 ; p=.278$ 
Chart 7 Do you consider yourself addicted to any kind of intoxicating substances to the extent that you could not do without them any more (cigarettes, alcohol)?

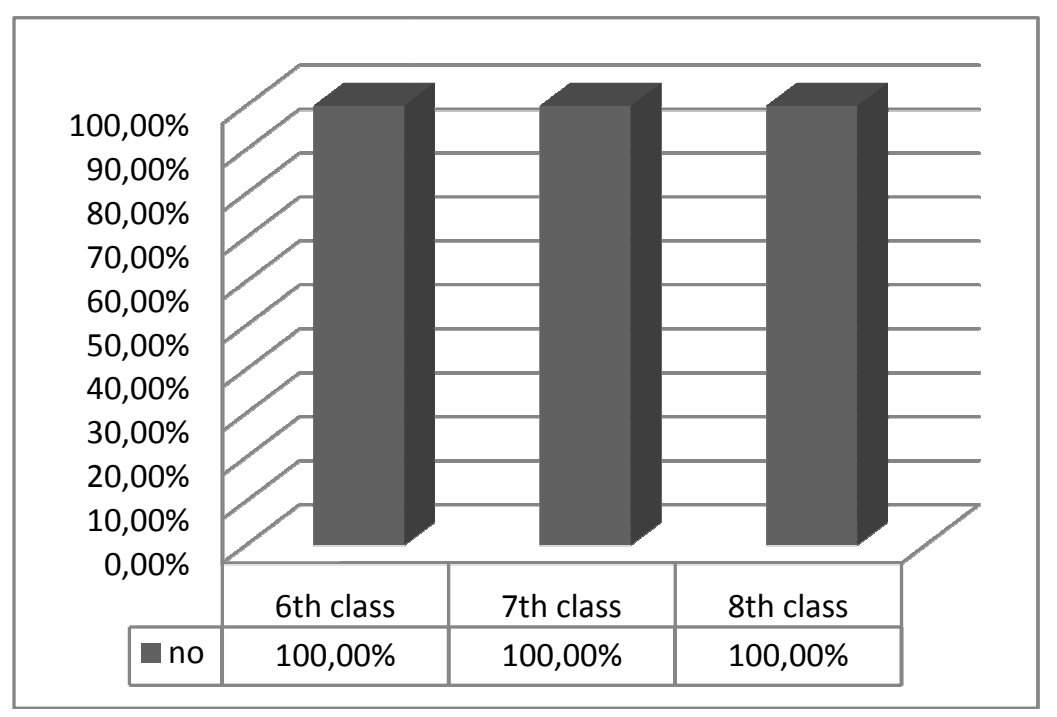

$x^{2}=$ constant

Chart 8 Do you think you are sufficiently and properly informed about this problem?

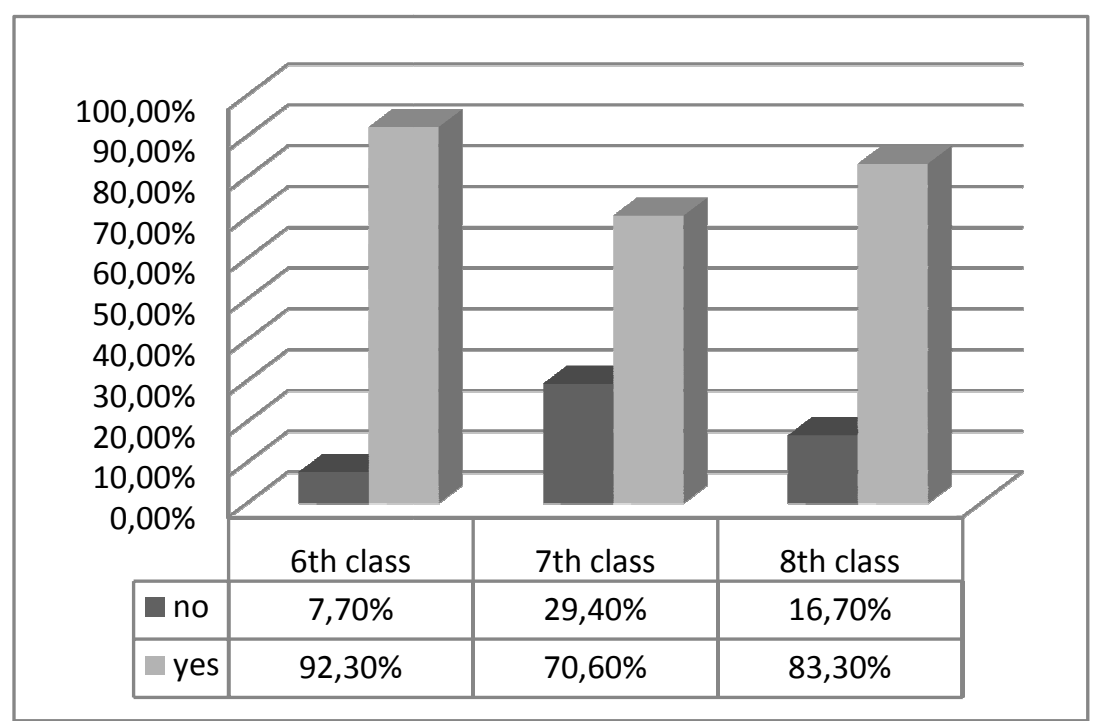

$x^{2}=23,150 ; d f=2 ; p=.031$

Over 70 percent of surveyed pupils thought that they were sufficiently and properly informed about the problem of addictive substances abuse (Chart 8). However, a little bit less than one-third of seventh graders considered that they were not 
sufficiently and properly informed about this problem, which means that a more significant preventive action in the form of giving information is necessary.

The value of the $x^{2}$ test for the variable sufficient and proper information about the problem of drugs among pupils is higher than the marginal value at the second degree of freedom, which means that the indicators can be taken as significant, not accidental.

\section{Conclusion}

This pilot research was aimed at gaining an insight into substance abuse in the Jože Šuran Elementary School in Višnjan - Branch School in Kaštelir. The obtained results show a relatively favourable situation of this school's pupils in relation to addictive substances.

The fact that a certain number of pupils considered that they were not sufficiently and properly informed about this problem, and the fact that a certain number of pupils was still experimenting with some addictive substances, mostly alcohol, should not be neglected.

However, in the interpretation of results it should be taken into consideration that this is a pilot research, conducted on a small sample of examinees, in a small community where the "social" control is higher when it comes to the correct upbringing of children and young people.

Schools should act more significantly in the direction of positive motivation in the everyday life of young people and offer experiences important for one's personal development in various dimensions. It can offer young people a possibility to work and exercise through various learning situations, which will be meaningful and of importance to them. Thus, a good school, with a favourable climate, can be a social area with a preventive influence on substance abuse. It must help young people to overcome adolescent difficulties and help them choose and try new ways leading to optimal growing up and social integration.

The obtained indicators make a valuable contribution to the planning of preventive and early interventions facing the problem of elementary school children addiction. The early identification of drug consumers is aimed at providing a timely intervention and help to such groups of young people in preventing occasional drug consumption and experimenting which could turn into addiction. All this needs the cooperation of parents, pupils, educational institutions, the local community and general public for a common goal of helping pupils to choose "healthy" behaviours.

\section{Bibliography}

1. Aarons, G.A., Brown, S.A., Coe, M.T., Myers, M.G, Garland, A.F., Ezzet-Lofstram R., Hazen, A.L., Hough, R.L. (1999): Adolescent alcohol and drug abuse and health. Journal of Adolescent Health. 6, 412-421. 
2. Bašić, J. (1995): Obitelj, rano otkrivanje i preveniranje poremećaja u ponašanju djece i mladeži. Društvena istraživanja. Zagreb. 18-19(4), 4-5. 563-573.

3. Brousselle, A., Gibeault, A., Vincent, M. (1980): Revue de quelques travaux psychanalytiques sur l'adolescence. Rev. Fr. de Psychanalyse. XLIV 3-4, 445-479.

4. Freud, A.(2000): Normalnost i patologija djece. Biblioteka Svijet dječje psihe, Prosvjeta, Zagreb.

5. http://www.hzjz.hr/skolska/Sazetak_ESPAD_2007.pdf - pristupljeno 02.09.2009.

6. http://www.hzjz.hr/ovisnici/ovisnici_epidem_08.pdf - Epidemiologija ovisnosti u Hrvatskoj, Hrvatsko zavod za javno zdravstvo - pristupljeno 25.10. 2010.

7. http://www.prevencija-ovisnosti-split.org/druga casopis.asp?id=11 - Služba za prevenciju ovisnosti i izvanbolničko liječenje Split - pristupljeno 12. 09. 2010.

8. Iverson, L (2005): Long-term effects of exposure to cannabis. Current Opinion in Pharmacology 5, 69-72.

9. Kocijančić, A (2010): Uporaba opojnih sredstava u Osnovnoj školi Jože Šurana VišnjanPodručna škola Kaštelir. Diplomski rad. Sveučilište Jurja Dobrile u Puli, Odjel za obrazovanje učitelja i odgojitelja. Mentor: dr.sc. Mirjana Radetić-Paić.

10. Maddox, S. J., Prinz, R. J. (2003): School Bonding in Children and Adolescents: Conceptualization, Assassment, and Associated Variables. Clinical Child and Familiy Psychology Review, 6 (1), 31-49.

11. Petak, O. (2005): Uloga Centra za socijalnu skrb u prevenciji ovisnosti. Zbornik radova: Stručna konferencija s međunarodnim sudjelovanjem «Borba protiv ovisnosti-borba za zdravu obitelj». Zagreb. 205-211

12. Radetić-Paić, M. (2005): Zloupotreba sredstava ovisnosti i rizični čimbenici u obiteljima djece $i$ mladeži s poremećajima u ponašanju grada Pule. Stručna konferencija s Međunarodnim sudjelovanjem "Borba protiv ovisnosti - borba za zdravu obitelj". Zbornik radova. str. 205. - 211. 
Metodički obzori 6(2011)3

Izvorni znanstveni rad

UDK: 613.83:364.272]:373.3(497.5 Kaštelir) Primljeno: 19. 5. 2010.

\section{ZLOUPORABA SREDSTAVA OVISNOSTI UČENIKA OSNOVNE ŠKOLE: PREVENIRANJE I RANO INTERVENIRANJE}

Antonia Kocijančić, stručna prvostupnica predškolskog odgoja, volonterka Dječjeg vrtića i jaslica "Radost" Poreč, Područni vrtić Kaštelir (Croatia) e-mail: antoniakoc@hotmail.com

dr. sc. Mirjana Radetić-Paić, Odjel za odgojne i obrazovne znanosti, Sveučilište Jurja Dobrile u Puli (Croatia) e-mail: mradeticpaic@ hotmail.com

doc. dr. sc. Maja Ružić Baf, Odjel za odgojne i obrazovne znanosti, Sveučilište Jurja Dobrile u Puli (Croatia) e-mail: mruzic@unipu.hr

\section{S a žetak}

Generalni cilj ovog istraživanja je steći uvid u zlouporabu opojnih sredstva učenika osnovne škole Jože Šurana Višnjan - područna škola Kaštelir u svrhu planiranja preventivnih i ranih intervencija usmijerenih ka tom problemu, kao i eventualnog provođenja daljnjeg istraživanja na većem uzorku ispitanika. Specifični cilj je utvrditi razlike uporabe sredstava ovisnosti po dobi (razredima) učenika, obzirom da se s adolescentskom dobi povećava rizik vezan uz eksperimentiranje s pojedinim sredstvima ovisnosti.

Dobiveni podaci pokazuju relativno povoljan odnos učenika promatrane škole prema zlouporabi sredstava ovisnosti i vrijedan su doprinos u planiranju preventivnih i ranih intervencija u odnosu na taj problem.

Ključne riječi: zlouporaba sredstava ovisnosti, osnovnoškolci, adolescencija, prevencija, rane intervencije, Kaštelir 